\title{
Gender Inequality and Emotions: Hostility against Women in Contemporary Turkey
}

\author{
Esra Sarioglu \\ Max Planck Insitute for Human Development
}

\begin{abstract}
How does gender equality influence the prevalence of hostile feelings among men towards women? Under which conditions are gender hierarchies in a society likely to provoke hostility and violence against women? By presenting a case study on vigilante violence in contemporary Turkey, this sociological research investigates the social and political foundations of hostile feelings encountered by women in Turkey. It shows that aggravated hostility is directed at particular groups of women and vigilante violence can be explained by a backlash thesis.
\end{abstract}

My research examines the detrimental effects of gender inequality on women by drawing on a case study on vigilantism against women in contemporary Turkey. Over the last few years, vigilante violence against women has been on the rise again in the country. Between September 2016 and July 2018, nineteen cases of vigilante violence against women were documented, where male vigilantes meted out violent punishments to women who failed to adhere to so-called moral norms in public places. I focus on vigilantism in Turkey to investigate the links between gender inequality and the prevalence of hostile feelings towards women. In particular, my research aims at identifying those specific forms of gender inequality in which women are more likely to encounter hostile feelings, aggression, and violence from men. Under which conditions does gender inequality generate hostile feelings, such as anger and aggression, towards women, causing serious damage? How do gender hierarchies aggravate women's historically constituted violability? And what role do hostile feelings play in the worsening of gender inequalities?

Such a research agenda is guided by sociological and historical thinking. What is not always immediately evident is the significance of the historical thinking about equality - that is, the idea that gender inequality is historically constituted and produced through various sites of power. My research, instead of uncritically taking for granted what it means to be unequal or equal, adopts a historical approach towards the notion of gender 
inequality, demonstrating an awareness of the fact that gender inequality displays different patterns and forms in different geographical settings that have come into being over time. For instance, during the $19^{\text {th }}$ century and the first half of the $20^{\text {th }}$ century, gender inequality was understood primarily in terms of women's exclusion from public and political life as citizens. In line with that, throughout the $20^{\text {th }}$ century, the sweeping changes in the gender system took place increasing women's participation in different spheres of public life as citizens, workers and students-just as men did. In the following period, women across the world gained the right to vote and the right to education. Some of these women swelled the ranks of the working poor, and others broke the glass ceiling of the labor market, taking up managerial positions, thanks to their success in higher education.

Despite this progress, inequalities between men and women persisted and were also accompanied by new forms of inequalities among women themselves. The trend toward better gender equality has stalled since the early 1990s, at least in advanced economies, with the movement of women into male dominated fields of work slowing down and women's participation in the paid labor market leveling off. For feminist scholars, this was largely because men have not comparably shifted into female-dominated fields of work, nor taken responsibility for household labor and childcare. ${ }^{1}$ This has resulted in a novel understanding of gender equality evolvingone that demands men to be more involved in the private sphere and to take up more family responsibilities, including childcare and housechores with the aim of creating a more equal gender division of labor. This novel understanding of gender equality, which was accepted not only in small feminist circles but also broadly in the mainstream policy-making community, was based on the idea that increasing participation of women in the public sphere depends on increasing involvement of men in the private spere. In a sense, all the social and political changes throughout the $20^{\text {th }}$ century forced the hands of policymakers to acknowledge previously ignored dimensions of gender inequality, reshaping the meaning of the term itself to fit the new social and historical context.

In social science literature, gender inequality is often analyzed by employing indicators such as women's employment status, disposable income, participation in decision-making processes, and women's mobility and health. Less attention is paid to the implications of gender inequality operating in the field of emotions. However, as studies have shown, emotions play an important role in making and unmaking social and political 
hierarchies. ${ }^{2}$ By drawing on the case of vigilantism against women, in which self-appointed vigilantes mete out punishments to those women whom they perceive to have transgressed the moral codes in Turkey, my research fleshes out the implications of gender hierarchies operating in the field of emotions. In particular, it carefully teases out the links between hostile feelings and violence women face and specific cases of gender inequality.

The tendency to neglect the importance of historicizing, which is often the case in the discussion of gender equality, becomes all the more evident when thinking about emotions. In common sense accounts, emotions are often regarded as ahistorical phenomena, static across time and space; their meaning and expression not open to change. Common sense thinking about emotions also tends to erase the social basis of emotions by over-emphasizing the view that emotions are what individuals have or feel depending on their psychological state. Recognizing the social basis of emotions is critical for my research on the hostile feelings women encounter in societies ridden by gender inequalities. My research project is based on the assumption that there is a cultural logic to emotions, as well as a historical and a social context, which allows us to see how emotions vary over time and are open to change. Emotions, of course, are associated with individual psychologies in as much as they are related to the mental and physical state of a person. Nevertheless, emotions are also related to history and society. Societies develop and organize their emotional practices with institutions such as the family, law, religion and the military; thus, setting norms and rules for feelings and their expressions, as well as priming individuals to feel certain ways in given situations towards certain things and people.

When seen from this perspective, it becomes possible to realize that hostility, like other emotions, is not only linked to individual psychologies, but is also inseparably connected to the broader dynamics of society and influenced by institutions such as the family, law, religion and the military that set norms and rules for the expression of hostility. As such, hostility towards women cannot be reduced to an individual attitudinal problem, but becomes associated with the larger organization of the society as well as with the hierarchies prompted by gender inequality. 
Hostility as a feeling suggests an animosity which often manifests itself in outward behaviors such as attacks or aggression which harm the victims of hostility. It encompasses a cluster of emotions such as resentment, anger and hatred. When feelings of hostility dictate the terms of human relations, social interactions between individuals or groups often take on aggressive or antagonistic forms, with each side coming to see the other as an enemy or an opponent. However, a generalized understanding of hostile feelings falls short of identifying the distinctly gendered dimensions of hostility that the cases of vigilantism against women in Turkey manifest.

Vigilantism against women in Turkey, as my research demonstrates, compels us to acknowledge that hostile feelings might have a gendered, if not distinctly sexist, component under certain conditions. A violent practice often carried out by individual men or small groups of men, vigilantism in Turkey has a gender dimension with the perpetrators being men and the survivors women. This gendered structure of vigilante attacks is a phenomenon that alerts us to the combined operations of sexism and hostility.

I use the term misogyny in my research to capture the pronouncedly sexist dimension of hostility that vigilante cases demonstrate. Often used to denote individuals' prejudices, misogyny refers to hostility against women. However, in their accounts of misogyny, feminist scholars, ask us to recognize the social basis of misogyny. ${ }^{3}$ Misogyny, these scholars argue, is rooted not in individual psychologies, but in social structures that shape and are shaped by gender hierarchies. Although the laws, rules and regulations put in place by the institutions limit the expression of hostility, they also enable its expression under certain circumstances towards particular groups or individuals. Once we acknowledge the social basis of hostile feelings, we can also see that institutions and the larger society, just like individuals, can also be hostile toward women.

I draw, in particular, on the concept of misogyny that Kate Manne put forth in her book Down Girl. Manne defines misogyny as a form of gendered oppression whose defining characteristic is hostility towards women. In this account, misogyny is regarded as a systematic social phenomenon "in which women are liable to encounter hostility due to the enforcement and policing of patriarchal norms and expectations - often, though not ex- 
clusively, insofar as they violate patriarchal law and order". ${ }^{4}$ In general, hostility toward those who are perceived as having violated or broken the law comes with the attitudes of retribution, punishment and exclusion. Likewise, in social contexts where male domination reigns, women's perceived violation of gendered norms comes with retributive and punitive feeling towards women. In these contexts, misogyny threatens to harm and punish a woman if she transgresses the moral norms-norms that keep gender inequalities and hierarchies intact. The same logic applies to vigilante violence; male perpetrators in Turkey do not target women across the board, but assault only those who allegedly transgress gendered moral norms.

\section{VIGILANTE VIOLENCE AGAINST WOMEN IN CONTEMPORARY TURKEY}

The punishment of women by men for their alleged offences against morality used to be a widespread misogynistic practice in Turkey, and has been historically enabled, to a certain extent, by norms around shame and honor, in which men maintain their honor by controlling women's sexuality. Throughout the early 2000s, however, vigilantism was far less common, and it seemed like the practice had been consigned to the dustbin of history until it resurfaced in Istanbul in 2015, where cafés and art galleries involved in so-called immoral activities, such as serving alcohol during an art exhibition, were threatened by resentful groups of religious, nationalist youths. In the same period, mixed-gender groups consuming alcoholic drinks in public spaces were intimidated by local small business owners. Vigilante incidents that exclusively target women, on the other hand, picked up pace after the democracy vigils in 2016. Instigated by President Erdogan, the vigils started on the night of July 15, 2016, when a faction of the Turkish military initiated a coup against the ruling Justice and Development Party (AKP). That night, Erdoğan appeared on a live CNNTürk broadcast via the anchorwoman's smartphone on FaceTime and called on the people to go out, violate the curfew, and stop the attempted coup. Held nightly for weeks in urban streets and squares, the vigils often drew thousands of participants. Never before had a government in the history of the Turkish Republic called the masses to the streets to display resistance against a military intervention. Tayyip Erdoğan's call on that night was 
met with enthusiasm by AKP supporters, and large masses of men and a small number of women took to the streets to join the vigils. During this period, men easily assumed the role of vigilantes protecting the regime. So it comes as no surprise that the first vigilante attack on a woman for her alleged moral transgression was reported just a few weeks after the vigils ended.

On September 12, 2016, Ayşegül Terzi, a 23-year-old nurse, was violently attacked on a public bus for wearing shorts. The male perpetrator defended himself in court by claiming that Ayşegül Terzi failed to dress modestly (Terzi v. Çakıroğlu 2016). Indeed, in all nineteen cases of vigilante violence documented so far, women have been assaulted for no other reason than wearing shorts, smoking cigarettes, sitting cross-legged in public, engaging public displays of affection, and exercising in parks, because all these behaviors are regarded by men to be a violation of gender norms.

To examine in detail the occurrences of vigilantism against women in Turkey, I drew on a diverse set of sources, including data on vigilante cases provided by women's organizations in Turkey, media reports, court cases, as well as the interviews I carried out in June 2017 and March 2018 with three feminist activists, three lawyers, and ten individual women who do not strictly observe the norms of feminine modesty. Whereas the interviews with the feminist activists and lawyers offered insights into the legal dynamics of vigilantism, by listening to the narratives of women who do not conform to localized norms about feminine modesty, I was able to understand how women navigate a social environment in which women are likely to encounter hostility.

I identified remarkable similarities among cases with respect to the gender of vigilantes as well as the gender of targets, the location of the vigilante attacks, and the justifications used by vigilantes to justify the attacks; however, the violent acts carried out by vigilantes differed, ranging from verbal assaults to brutal physical attacks. In terms of the gender of vigilantes and victims, vigilantes were exclusively male, while victims were women who allegedly violated gendered moral norms in public places. Women whose demeanor, posture, confidence, elocution, dress, and bodily comportment does not comply with a particular set of norms about feminine modesty are the ones who are most likely to be subjected to vigilante violence.

Justifications male vigilantes provide also exhibit remarkable similarities. Justification concerns how perpetrators legitimize their actions to the public, which includes witnesses to the action, the media and state officials. Generally speaking, the justifications perpetrators utilize might range from moral to legal, but often a single desire underlies these diverse justifi- 
cations: to reinstate a particular order, whether it be a legal, racialized, gendered, or religious order. In the case of Turkey, the justifications perpetrators used overwhelmingly indicated a desire to reinstate a moral order. In other words, all the vigilante attacks fit into the category of moral vigilantism, where violence or threat of violence is cloaked in an appeal to higher moral orders and religious powers. Vigilante men call upon a moral order, rather than another, such as a legal order, when justifying their attacks. This, of course, is not surprising given that women's outwardly physical acts, including wearing shorts, smoking cigarettes, and sitting cross-legged in public are not classified as a range of behaviors that are illegal or criminal, and thus punishable by the state. Moreover, vigilantism is a criminal act under Turkish law and in those cases that went to court, vigilante men were convicted of assault and received sentences. The legal order, based on the principle of equality, constrains men's efforts to dominate women, whereas the field of morality, as the vigilante cases in Turkey illustrate, enables men to claim and use coercive power over women's bodies.

Acts of vigilantism took place in public spaces in densely populated cities such as Izmir, Antalya, Istanbul, Bursa, and Adana. Indeed, the recent resurgence of vigilante violence against women is limited to large cities; in small towns and rural areas, norms about feminine propriety and modesty have always been strict. This finding is actually surprising given that densely populated cities in Turkey have historically been places where gender norms are lax and where the public presence of the women who do not conform to norms of propriety has been fairly strong. However, the rise of vigilantism against women over the last few years illustrates that women who live comfortably in large cities thanks to relaxed gender norms are at an increasing risk of becoming the victim of vigilantism in today's Turkey. Why has hostility towards the women who do not conform to strict gender norms begun to crop up in those cities where gender norms are already relaxed?

\section{IMPROVED GENDER EQUALITY AND AGGRAVATED HOSTILITY AGAINST WOMEN: A BACKLASH AGAINST WOMEN?}

In order to better address this seeming paradox, I began to ask questions about the link between violence against women and gender inequality. I also began to review the assumptions made about the causes of male violence in the social science literature. Male violence against women is conventionally regarded as a sign of women's subordination and it is often attributed to the uncontested operations of gender hierarchies. However, in 
Turkey, it was insubordinate women who faced aggravated hostility. This led me to take the backlash hypothesis into consideration as a means of explaining the increasing levels of hostility towards women. In those cases where there is backlash against women, violence against women is provoked not by women's subordination but by women's empowerment. Men might have a strong negative reaction to improvements in gender equality and might resort to physical violence to compensate for their lack of control over women.

Are women really more empowered in Turkey? Can we talk about improvements in gender equality in Turkey? There is already some empirical evidence to suggest that, over the last two decades, gender equality has become more entrenched in legal structures. Since the foundation of the Turkish Republic in 1923, gender equality, has been inscribed in the law and functioned as a pillar of the secular republic. However, the legal framework was full of sexist clauses that acknowledge men as the head of the households or that stipulated different treatment of virgin and non-virgin women in a penal code which was adapted from the Italian penal code. In the early 2000s, the AKP government restructured the legal system, with the adoption of a new Civil Code and Penal Code. Initially, these reforms were carried out as part of Turkey's candidacy for joining the European Union and the government was not really invested in deepening gender equality in the country. However, the feminist movement in Turkey, which is quite strong and militant, seized this moment and exerted mounting pressure on the government through lobbying and activism. Thanks to feminists, what started as a minor legal change that took no account of women's needs has grown into full-blown legislation which has strengthened gender equality in the country.

The new gender equality legislation improved women's bodily rights, including the rights to bodily integrity and bodily security. For example, enforced virginity tests, which scholars defined as a "particularly modern form of institutionalized violence" ${ }^{5}$ were banned during this period. The virginity test, vaginal examinations performed on women by doctors, was a common practice that aggravated women's bodily violability. In 2004, a new penal code was introduced. The new penal code outlawed the violation of women's bodies by using the pretext of so-called moral concerns, such as public morality, honor and chastity. ${ }^{6}$ 
These legal changes, together with the increase in women's educational attainment levels and labor force participation rates, unsettled the otherwise secure basis of gender hierarchies in Turkey, thus diminishing men's power over women. These initial gains in gender equality triggered a backlash, where men attempted to regain their lost power; namely, the power to control women's bodies. It is in this context that changes to gender inequality generate an aggravated pattern of hostility towards women. This hostility takes the form of punishment and refuels the patriarchal operations of power. It is often those women with increased autonomy and empowerment who become targets of this aggravated hostility.

My research asks us to pay more attention to the perils of improving gender equality in precarious political regimes. Vigilante attacks broke out in a period when the AKP government, following a failed coup attempt in 2016, further strengthened its grip on power and deepened its authoritarian rule. In this volatile period, women, who had been empowered by the gender reforms of the early 2000s, easily turned into targets of hostility. The AKP government's political efforts to undermine gender equality as well as the rule of law went hand in hand with the intensified workings of power, violence and exclusion. This set the stage for aggravated hostility against empowered women, provoking the eruption of vigilante violence in big cities.

\section{REFERENCES}

Barbalet, Jack. (2001). Emotion. Social Theory, and Social Structure: A Macrosociological Approach. Cambridge University Press.

England, Paula. (2010). The Gender Revolution: Uneven and Stalled. Gender \& Society 24(2), 149-166.

Frevert, Ute. (2020). The Politics of Humiliation: A Modern History. Oxford University Press.

İlkkaracan, Pınar. (2007). Reforming the Penal Code in Turkey: The Campaign for the Reform of the Turkish Penal Code from a Gender Perspective. Institute of Development Studies, 1-28.

Manne, Kate. (2017). Down Girl: The Logic of Misogyny. Oxford University Press.

Parla, Ayse. (2001). The 'Honor' of the State: Virginity Examinations in Turkey. Feminist Studies 27(1), 65-88.

Sayer, Andrew. (2005). Class, Moral Worth and Recognition. Sociology 39(5), 947963. 


\section{ABOUT THE AUTHOR}

\section{Dr. Esra Sarioglu}

Esra Sarioglu received her $\mathrm{PhD}$ in sociology from Binghamton University in 2013 and is currently a researcher at the Center for the History of Emotions, Max Planck Institute for Human Development, Berlin. Between 2016 and 2019, she worked as an assistant professor in the Gender Studies Division of the Department of Political Science and Public Administration at Ankara University, where she also served as vice-chair of the Women's Studies Center. Her research interests include gender and globalization, embodiment, emotions, work and labor, and gender politics in Turkey. Her current research focuses on gendered schemas of shame and the transformation of body politics in contemporary Turkey. Her work has appeared in Gender, Work \& Organization, Women's Studies International Forum, Safundi: The Journal of South African and American Studies, and Kadın/Woman 2000. She has also published several book chapters and essays in Turkish and English. She is the Managing Editor of Mülkiye Dergisi, a quarterly peer-reviewed journal that provides a forum for research focusing on social and political dynamics in Turkey.

\section{Selected Publications:}

Sarioglu, Esra. (2018). Vigilante Violence against Women in Turkey: A Sociological Analysis. Kadin/Woman 2000, 19(2), 51-68.

Sarioglu, Esra. (2018). The aesthetics of minor intimacy: precarious attachments and queer feelings in the autobiographical fiction of JM Coetzee. Safundi: The Journal of South African and American Studies 19(4), 461-481.

Sarioglu, Esra. (2018). From sister to co-worker: new patterns of feminization of labor in Turkey. In B. English, M.E. Frederickson, and O. Sanmiguel-Valderrama (Eds.) Global Women's Work: Perspectives on Gender and Work in the Global Econo$m y$. Routledge.

\section{ABOUT THE INSTITUTE}

Max Planck Institute for Human Development, Center for the History of Emotions

The Center for the History of Emotions has a robust research agenda that examines the complex ways in which emotions are integrally bound up with the individual, as well as with social and historical forces. Such an 
agenda opens up a new direction for research that explores an underexamined area of the interactions between emotions and social relations of power and domination. Esra Sarioglu's research, by focusing on Turkey, investigates how emotions are integrated into gender hierarchies as a central category of analysis and explores how emotional practices stemming from hostility interacts with gender inequality and violence against women. 
